\title{
The Lower Danube and Romanian Nation-Making
}

We accept the strictest regulations designed to ensure freedom for all flags, we accept the most rigorous control for the application of these regulations, but we want to see that in Romanian waters these regulations are applied by Romanian authorities.

KING CHARLES I OF ROMANIA, 1881

On 17 September 1883, Friedrich Martens, an Estonian-born diplomat and law professor, better known as the editor of a large collection of Russian diplomatic documents and as an active supporter of international arbitration and conciliation, sent a letter to Alphonse Rivier, the Swiss scholar who at the time served as secretary general of the Institute of International Law (IIL). The organisation had been founded a decade earlier in Ghent (Belgium) by several dozen legal scholars who aimed 'to contribute to the progress of international law and become the legal conscience of the civilised world.' Martens' missive, published in the Institute's journal, Revue de droit international et de législation comparée, was an appeal for the IIL to get involved, according to its status, in settling the juridical principles 'upon which the international regulation of navigable rivers accessible to all nations should be based'. Such a normative work would render 'a great service both to the practice and to the science of international law', given the 'exceptional importance' that the navigation of international rivers enjoyed at the time. ${ }^{2}$

Martens bolstered his intellectual endeavour with references to the deviations from the legal principles proclaimed in 1815 as part of the 'public law

1 Martti Koskenniemi, The Gentle Civilizer of Nations: The Rise and Fall of International Law 1870-1960 (Cambridge 2001), 41.

2 'Lettre de M. de Martens concernant la navigation des fleuves internationaux,' Revue de droit international et de législation comparée (hereafter RDILC) 15 (1883): 626-627. 
of Europe'. Serious inconsistencies had resulted in 'conflicts of opinion and misunderstandings' that had erupted, especially during a recent ambassadorial conference hosted in London, 'between the great European powers, on the one hand, and Romania, on the other'. Martens alluded to the meeting of representatives of Europe's Great Powers in London, in February-March 1883, for settling the international regime of the Danube, in continuation of preliminary decisions taken at the 1878 Berlin Congress. However, Romania, one of Europe's youngest independent states, stubbornly refused to accept the compromise reached in Europe's Concert. This solution allegedly violated its sovereign rights as a riparian state on the Lower Danube. The press followed the story with great interest, and various juridical views were popularised throughout Europe. It was, according to Martens, a 'confusion of ideas' which 'could have very unfortunate consequences, and even provoke serious conflicts between nations. ${ }^{3}$

The Institute accepted the request, and a study committee was soon created. With Martens himself, Rivier, Baron Franz von Holtzendorff (freshly elected president of the IIL at its 1883 Munich meeting), Egide Rodolphe Nicolas Arntz of Brussels University, Louis Renault from Paris, Donald James Mackay (Lord Reay), Sir Travers Twiss, and Lorenz von Stein, some of the world's brightest legal minds were set to analyse the issue at a time when the employment of international rivers was eyed by imperial powers around the world.

Juridical experts in transnational epistemic communities had also closely followed Romania's diplomatic conflict with its former protectors. It was, to them, an issue which could have major consequences for the stability of the international system due to the simple, but essential question that lay at its core: finding the proper balance between 'the rights of a small state' and the 'interests of a great power'.4

Starting from such premises, this chapter aims to follow Romania's fight to defend its territorial sovereignty in $1878-1883$, and how this dispute influenced the situation of the European Commission of the Danube, the international organisation that gained new functions and further prestige on the Lower Danube. This involves diving deeply into international relations and Romanian domestic politics at a time when Europe's political-military alliances and Romania's political establishment were both undergoing structural

3 Ibid.

4 Franz von Holtzendorff, Les droits riverains de la Roumanie sur le Danube: consultation de droit international (Berlin 1884), 100. A recent work that illuminates 'the relations between the imperial powers of Western Europe and states and societies outside Europe' is also relevant in this case - see Jennifer Pitts, Boundaries of the International: Law and Empire (Cambridge MA 2018). 
changes. In this fluid context, the Danube Question contributed to turning the Commission into a fully-fledged actor of the international system, whose agency was to prove vital in securing the stability of southeastern Europe. The chapter will navigate between the second and the third layers of analysis, aiming to show how an IO regarded larger European security issues and how they, in turn, influenced decisions taken at Galați.

From several perspectives, the political career of Mihail Kogălniceanu (18171891) epitomises the making of modern Romania. The scion of a wealthy Moldavian boyar family, Kogălniceanu was educated in Lunéville and Berlin, in environments filled with French revolutionary ideals and more temperate forms of German nationalism and reformism. His passion for history and scholarship was boosted by his meetings with personalities such as Alexander von Humboldt or Leopold von Ranke. An early advocate of Romanian nationmaking, Kogălniceanu published a synthesis of Romanian history in 1837, and later returned to his native lands with many others in the young westerneducated boyar elite who aimed to instil in the Principalities a rather strange mixture of enlightened, liberal and socialist ideas. From the 1840s, Kogălniceanu was actively involved in Moldavia's intellectual and political life, and in the 1860s, as prime minister of united Romania, he imposed one of the most transformative political programmes in the country's history, with agrarian and electoral reforms, an educational law, and the introduction of the Napoleonic code. Kogălniceanu survived the deposition of his princely partner, Alexandru Ioan Cuza, and continued to hold high-ranking offices in several liberal governments that followed the enthronement of the Prussian Charles I (Carol) of Hohenzollern-Sigmarigen (r. 1866-1914) as Prince of Romania. ${ }^{5}$

One of the top priorities of Romania's political leadership was to remove the formal suzerainty of the Ottoman Empire, and the Eastern Crisis of the mid-187os was an opportunity to move the diplomatic agenda closer to state independence. Kogălniceanu served as Foreign Minister for a short term in April-July 1876 , when war was raging in the Balkans. He tried to negotiate with the Porte about the pending issues that loomed over Romanian-Ottoman bilateral relations; one of them concerned the border settlement in the Danube Delta and Romania's aspirations to have unobstructed access to the sea. In a dispatch to Safvet Pasha, the Ottoman Foreign Minister, Kogălniceanu referred in extenso to the Vylkovians' plight (Chapter 3) and urged for a compromise

5 Alexandru Zub, Mihail Kogălniceanu: un arhitect al României moderne (Iași 2005). 
over a territory (the Danube Delta), which had been 'in Moldavia's patrimony for centuries'. ${ }^{6}$ However, Kogălniceanu's proactive and militant diplomacy risked fuelling the Balkan fire at an inexpedient time, and his party had him replaced with Nicolae Ionescu, a rather obscure politician, but a vowed adept of neutrality.

Diplomatic bargaining continued in Istanbul, where Romania's claims were regarded as unreasonable. With Russia preparing for war, Kogălniceanu was reinstated as Foreign Minister in April 1877, and he immediately signed a convention that allowed the passage of Russian troops through Romanian territory, which moved the battlefield further south to Bulgarian lands. Russia declared war on the Ottoman Empire on 24 April 1877. Romania followed suit, and a month later proclaimed its state independence. Unexpectedly, the assistance of Romanian troops proved decisive for Russia's cause during the siege and fall of the strategic Ottoman stronghold of Plevna in Bulgaria, and with the nation spilling its sons' blood, the country had great expectations from the future peace conference. Besides international recognition of state independence and indemnities for its human and material loss, the government also contemplated the levelling of Ottoman citadels on the right bank of the Danube and the return of the Danube Delta, unjustly seized by the Porte. ${ }^{7}$

For Kogălniceanu, as for Romania's entire political elite, this decision of European statesmen in 1857 (Chapter 2) had been a mistake for very evident reasons. Modern Romania had been created as a buffer state between imperial rivals in southeastern Europe with the mission of guarding a symbolic border, the Lower Danube. The Romanian Question and the Danube Question had been two of the major disputes of the Crimean War diplomacy, which then divorced them by granting the Danube Delta to the Ottoman Empire. If, for larger geopolitical calculations and the balance of power on the continent, vassal Romania was just an Ottoman outpost, Romanian patriots thought it was high time to let the country fulfil its true function - that of an independent and neutral buffer state strategically placed in between empires. Their political model, both in terms of constitutional organisation and international status, was Belgium. ${ }^{8}$

What Romania lacked was control of the Maritime Danube, a vital section not only for the economic interests of Great Britain and Austria-Hungary, but for its own survival. Grain accounted for more than 80 per cent of Romania's

6 Ministerul Afacerilor Străine, Documente oficiale: neutralitatea Romaniei, neutralisarea Dunarei, diverse (Bucharest 1876), 76-77, 84-88.

7 Ministerul Afacerilor Străine, Documente oficiale din corespondența diplomatică de la 5/17 octombrie 1877 până la 15/27 septembrie 1878, presentate Corpurilor Legiuitoare în sesiunea anului 1880-1881 (Bucharest 1880), 9-10.

8 Frederick Kellogg, The Road to Romanian Independence (West Lafayette 1995), 14. 
exports, and the ports of Brăila and Galați were the 'lungs' of its economy. Without the Danube, Romania's economy could not grow properly, although it was not completely suffocated, as had happened in Russian times before 1856 . The Lower Danube was one of the pillars of modern Romania's national existence, which buttressed the country's economic prosperity and international political status. To Alexandru Lahovary, a vocal conservative politician during the 188 os, Herodotus' simile applied perfectly to the Romanian case: just as 'the Nile made Egypt, we can also say that the Danube created the political and economic importance of Romania.' 9 The construction of Romania's identity as a 'gift of the Danube' was completed by the 1870 s, and European presence on the Maritime Danube, materialised in the Commission, was further proof that Romania and Europe shared similar interests in the general prosperity and stability of southeastern Europe. Danube

The conclusion of the Russian-Ottoman armistice in January 1878 was a major blow to Russian-Romanian relations. Romania's envoy was not invited to the negotiations, and Russian diplomats gave formal assurances that they would watch over the interests of their military ally. The Bucharest government's worst fears came true after being notified that Russia would annex Southern Bessarabia, in exchange for which Romania was to receive ample territorial compensation. For Russia and for Alexander II personally, the reannexation of Southern Bessarabia was 'a question of honour and national dignity', which would remove the last stains of the ill-fated 1856 Paris Treaty. Romania, it was added, would earn more by accepting a very profitable deal without turning the issue into an international dispute. ${ }^{10}$

For Romanian statesmen, this was a difficult exercise in political realism. In a letter to General Ion G. Ghica, Romania's diplomatic agent to St Petersburg, Kogălniceanu gave full vent to his countrymen's dissatisfaction:

9 Alexandru Lahovary, Interpelarea domnului Alexandru Lahovary în chestiunea Dunării (Bucharest 1881), 3 .

10 Barbara Jelavich, Russia and the Formation of the Romanian National State, 1821-1878 (Cambridge 2004), 268; the context in Sorin Liviu Damean, România și Congresul de Pace de la Berlin (1878) (Bucharest 2005), 49-62. 
It is unworthy of a great empire to thus deceive a country that had given up everything on the assurances alone that the word of an emperor is worth more than a treaty. If they had wanted to despoil the Romanians of a part of their patrimony, it would have been honest to tell them that before the conclusion of the convention of April 4, before we crossed the Danube, before we saved the imperial army and perhaps the emperor at Plevna ... Then it would have been better to let the Turks be victorious, for they certainly would not have taken from us some of Bessarabia in case of victory.11

The Foreign Minister's counterfactual argument was much exaggerated and self-eulogising, but his frustration over the nation being unfairly treated after Romania's greatest military success yet was genuine and widespread among his compatriots.

To many diplomats around Europe, Russia's claims were hardly surprising. The recovery of Bessarabia was, in fact, one of Russia's few clear aims during the war, ${ }^{12}$ and it had been duly communicated to Europe's powers in bilateral negotiations during the previous years. Both in the Reichstadt Agreement of July 1876 and the Budapest Convention of January 1877, Austria-Hungary agreed to Russia's intention of restoring its sovereignty over Southern Bessarabia. Statesmen in Bucharest were also fully aware of Russia's determination to put an end to the infamous 1856 Paris Treaty, but they hoped that Romania's active involvement in the war and Prince Charles' personal relations with the imperial family would save the much-disputed province. With his historical background and political experience, Kogălniceanu could easily guess that, without strong international support, Bessarabia was a lost cause, and that it was perhaps wiser to listen to Russia's offer and accept the spoils of war.

But, for now, the nation had to stand united against its former ally. With Russophobic sentiments ripening among the country's educated classes, this was hardly difficult. A motion against Russia's territorial rapaciousness was passed in the Parliament in February 1878 with unanimous support from both sides of the political aisle. The government sent a memorandum to the European powers explaining Romania's position, and the importance of its keeping Bessarabia and being granted the Danube Delta, given the country's mission 'to guard, with energy and steadiness, free navigation on the Danube.'13

\footnotetext{
11 Jelavich, Russia, 269-270.

12 A.J.P. Taylor, The Struggle for Mastery in Europe 1848-1918 (London, Oxford and New York 1971), 246.

13 Damean, România, $55^{-56}$.
} 
The press was equally unanimous in its defence of Bessarabia, a territory which until that moment was completely peripheral in Romanian public opinion. ${ }^{14}$ Not only its southern part, but the entire province, annexed by Russia from Moldavia in 1812, became the focus of a nationalist, anti-Russian discourse.

One of the most critical voices of the time was that of Mihai Eminescu (1850-1889), nowadays regarded as Romania's greatest poet. As an editor at Timpul, the mouthpiece of the conservative opposition, Eminescu lost no opportunity in slamming the liberal government for its weakness in defending the country's national body. He wrote extensively about the loss of Bessarabia, which was 'a question of existence for the Romanian nation'. Russia was a 'large and powerful empire, and we are a small and weak country. If Tsar Alexander II is determined to take Bessarabia under his rule, it is lost for us'. But it was not so much a matter of losing or keeping a province: 'the question is how we lose it or how we keep it'. Romania stood not just to lose territory but 'the confidence in the stamina of the Romanian people'. By

losing the land that dominates the mouths of the Danube, Romania becomes an insignificant state, whose existence or nonexistence would no longer be of any interest. [...] With the country open to the north and facing a strong neighbour, our strength can only consist in the economic interests that the West has for the Danube waterway and the Black Sea. So, there is no equivalency for this strip of land placed on the left bank of the Danube.

The compensation that Russia offered, Ottoman Dobrudja in exchange for Bessarabia, was a poisonous gift. ${ }^{15}$ Public opinion was inflamed on this issue, and Romanian statesmen had their hands tied in negotiating with Russia. European support was vital, though it was highly improbable that any power would intervene to defend a small country tricked by its own ally. The only way of turning a national wound into an international question was to insist on the direct connection between political control over the Bessarabian districts and free navigation on the Danube. In 1856, Russia had been stripped of this territory by a decision of the western powers, which aimed to push the empire further away from the river to give additional security to the principle of free navigation. By reannexing Southern Bessarabia, Russia hurt not only its former

14 More in Andrei Cușco, A Contested Borderland. Competing Russian and Romanian Visions of Bessarabia in the Late Nineteenth and Early Twentieth Century (Budapest 2017).

15 Mihai Eminescu, Opere, vol. v, Publicistică, 1 noiembrie 1877-15 februarie 1880, Timpul (Bucharest 2010) (În numărul nostru de vineri ..., 19 February 1878), 133. 
ally, but also major international economic and political interests in the Lower Danube. London and Vienna were the capitals where this message could effectively be delivered.

The San Stefano Peace Treaty (3 March 1878) was concluded amidst growing tensions between Europe's Great Powers. Romania, Serbia and Montenegro were recognised as independent states, but it was the creation of the autonomous principality of Greater Bulgaria, stretching all the way to the Aegean Sea, that seemed to completely unbalance the already unstable Balkans. Articles 12 and 13 referred to the neutral and international character of the Danube (with the preservation of all rights, obligations and prerogatives of the Commission), and Article 19 mentioned the reprehensible territorial exchange: Dobrudja and the Delta Islands in exchange for Southern Bessarabia. ${ }^{16}$

The British and Austrian-Hungarian cabinets were discontented with the overall results of the peace settlement, and the cabinet in Bucharest focussed its diplomatic efforts in these directions. Ion Bălăceanu, Romania's agent to Vienna, reported that diplomatic resistance in the Bessarabian/Danubian Question depended on the position of the London cabinet, ${ }^{17}$ which had to defend its large share of the Lower Danubian shipping. Political forces in Britain regarded Romania's frustration over Bessarabia as legitimate and useful for checking 'the expansion of Slavism' and considered that Romania, together with Greece, could act as agents of 'Western interests and civilisation' in southeastern Europe. ${ }^{18}$ In a speech to the House of Commons in April 1878, Prime Minister Benjamin Disraeli, Lord Beaconsfield, defended Romania's territorial rights and referred to Britain's own historical role in securing free navigation on the Danube:

The Clause in the Treaty of Paris with regard to the cession of Bessarabia was one on which Lord Palmerston placed the utmost stress, and to which he attached the greatest gravity. It involved, he said, the freedom of the Danube, and, accordingly, Lord Palmerston treated it as an Article, not of local, but of European interest. It was inserted in the original Preliminaries of the Treaty, and an attempt was made subsequently by Russia to evade it; but Lord Palmerston attached such importance to it

\footnotetext{
16 Documents Diplomatiques. Affaires d'Orient. Congrès de Berlin 1878 (Paris 1878), 21-31.

17 Vasile Kogălniceanu (ed.), Acte și documente din corespondența diplomatică a lui Mihail Kogălniceanu relative la războiul independenței României 1877-1878, vol. I, fasc. I (Bucharest 1893), 137-139.

18 Nicolae Iorga, Correspondance diplomatique sous le roi Charles Ier (1866-1880) (Bucharest 1938), 330-331; the international context in Dwight E. Lee, 'The Proposed Mediterranean League of 1878,' Journal of Modern History 3 (1931): 33-45.
} 
that, at one time, the Congress of Paris was near breaking up because of the efforts made by Russia to escape from that Article. ${ }^{19}$

Similar sympathy came from the Liberals and William Ewart Gladstone, who protested 'the mutilation of Roumania' and expressed the hope that Russia would not 'stoop to this petty spoliation from a humble but brave ally'. ${ }^{20}$

But beyond such formal support, there was little to be done, and by April Russia and the other Great Powers were busily bargaining on pending issues. Chancellor Alexander Gorchakov called for 'calm and moderation', explaining that the annexation of Southern Bessarabia was a mere return to a situation altered in 1856 for reasons that no longer needed to exist. There was no connection between the exchange of territories and the freedom of navigation on the Danube, guaranteed by an IO, and which was to be carried out on the territory of a sovereign state, Romania. In subsequent arrangements, Russia greatly reduced its claims in the Caucasus and accepted a significant trimming of Bulgaria's southern borders, but the Bessarabian restoration was nonnegotiable. It was a question of 'national honour and dignity', which was to be resolved irrespective of the vilification of an ungracious former protegee that owed Russia not just its state independence, but its very political existence. ${ }^{21}$

With active bargaining throughout Europe's capitals, the provisions of the San Stefano Treaty were soon absorbed into the Great Powers' politics of multilateral concessions and compromises, and freedom of navigation on the Danube was included among the strategic issues that had to be regulated and safeguarded during the future European congress. Romanian diplomats were not fully aware of all stipulations included in the secret agreements that paved the way for the organisation of the Berlin Congress. But it was clear that disagreements would be solved by bargaining, and it became vital for the cabinet in Bucharest to be represented at the forthcoming congress and to convince the nation that its diplomats were fighting for the country's territorial integrity and historical rights.

19 Hansard's Parliamentary Papers, vol. 239 (London 1878), 771.

20 R.W. Seton-Watson, Disraeli, Gladstone and the Eastern Question. A Study in Diplomacy and Party Politics (London 1962), 489; more on Romanian-British relations in Andrei Căpușan, Evoluția relațiilor româno-britanice, vol. I, 1876-1880, vol. II, 1880-1886 (Bucharest 2003 and 2006) and Constantin Ardeleanu, Evoluția intereselor economice și politice britanice la gurile Dunării (1829-1914) (Brăila 2008).

21 Iorga, Politica externă a regelui Carol (Bucharest 1916), 270; Spiridon G. Focas, The Lower Danube River: In the Southeastern European Political and Economic Complex from Antiquity to 1948 (New York and Boulder 1987), 345-346. 
The Maritime Danube played a central role in Romania's defence strategy in 1878 . The country was fated to be the guardian of the Danube and of its free navigation, regarded as a vital European economic and political interest and threatened by the hegemonic tendencies of Russia and Austria-Hungary. This leitmotif was reinforced in the following years, and the Danube Question, as it unfolded in 1878-1883, contributed decisively to shaping Romanian nationalism. ${ }^{22}$

\section{Europe's Concert and the Danube Question}

Europe's top statesmen were summoned to Berlin in mid-June 1878 to harmonise the 1856 Paris Peace Treaty with the new political realities of southeastern Europe. Notwithstanding previous arrangements, opposition against Russia was not mere parade, and the Danube Question was discussed during several official meetings in Berlin. On 29 June, European plenipotentiaries analysed the articles concerning Romania in the San Stefano Peace Treaty. Lord Beaconsfield referred in detail to the reappropriation of Bessarabia by Russia, which was more than 'a simple exchange of territories between two countries'. Moreover, as the British government could find no guarantees for the free navigation of the Danube, Beaconsfield waited for Russia's pledges to safeguard it. Gorchakov saw no connection between the Bessarabian and the Danube Questions. Free navigation, which was indeed a 'European interest', was not to suffer after the return of Bessarabia. Count Pavel Shuvalov, Russia's second plenipotentiary, added that the recovery of Bessarabia could be considered 'a matter of ambition and interest', but also 'a matter of honour' which was not motivated by a desire 'to interfere with the free navigation of the river'. Bismarck recognised the importance of the free navigation principle but agreed that for lasting peace on the continent, Russia's reasonable claims had to be observed. ${ }^{23}$

Romania's delegates, Prime Minister Ion C. Brătianu and Foreign Minister Kogălniceanu, presented the country's position on 1 July. In his long historical

22 Richard Frucht, 'War, Peace, and Internationality: The Danube, 1789-1916,' in: Southeast European Maritime Commerce and Naval Policies from the Mid-Eighteenth Century to 1914, edited by Apostolos E. Vacalopoulos, Constantinos D. Svolopoulos and Béla K. Király (Boulder and Highland Lakes 1988), 79-97. The process is similar to that played by the Rhône in France - Sara B. Pritchard, Confluence: The Nature of Technology and the Remaking of the Rhône (Cambridge MA 2011), 10.

23 Documents Diplomatiques, 157-161; Dimitrie A. Sturdza, Recueil de documents relatifs à la liberté de navigation du Danube (Berlin 1904), 112-116 (Protocol 9, 29 June 1878). 
and juridical exposé, Kogălniceanu requested, among other things, the maintenance of Romania's territorial integrity and the return of the Danube Delta to the Romanian nation, its true master, under the assurances that an independent and neutral Romania had no other ambition but to be 'the faithful guardian of Danube's freedom at its mouths' and to develop the country's institutions and material resources. ${ }^{24}$

Discussions continued on 2 July, when Baron Heinrich Haymerle, AustriaHungary's plenipotentiary, presented a new version of Article 12 of the San Stefano Peace Treaty, which outlined Vienna's Danubian policy after Russia's return as a riparian state to the Maritime Danube. Haymerle proposed the neutralisation of the Danube on the section downstream of the Iron Gates (i.e. outside the empire's territorial reach) and a new status for the Commission, which was to include Romania, but stay independent of its territorial authority. Navigation rules on the Fluvial Danube were to be harmonised with those drafted by the Commission, and Austria-Hungary requested an exclusive right to carry out the technical works necessary for improving the navigability of the Iron Gates and to levy charges for covering the costs of such works. Other plenipotentiaries required more time to study the proposals, whereas Bismarck opposed any further debates, as the congress was tasked to accept, reject or modify the San Stefano Treaty, not to analyse in detail the future organisation of the Danube's regime. ${ }^{25}$

Two days later, Shuvalov came back with a counterproject which did not refer to the neutralisation of the Danube, but guaranteed freedom of navigation for all nations, and proposed maintaining the Commission and harmonisation of the 1865 Public Act through a special commission, with the participation of riparian states. The differences between the two projects required an agreement between Russia and Austria-Hungary, mediated by France. The compromise stood at the basis of the final decisions concerning the Danube inscribed in the Berlin Peace Treaty of 13 July $1878 .{ }^{26}$

Beyond sanctioning the exchange of territories (Southern Bessarabia for Dobrudja and the Danube Delta), the treaty referred to the Danube Question in articles 47 and $52-57$. Article 47 entrusted the Commission with mediating the delimitation of waterways and fisheries in the Danube Delta, and Article 52 mentioned the demolition of fortifications along the river downstream of the Iron Gates and prohibited the navigation of warships on this section, except

24 Documents Diplomatiques, 161-166 (Protocol 10, 1 July 1878).

25 Ibid., 178-180; Sturdza, Recueil de documents, 116-119 (Protocol 11, 2 July 1878).

26 Documents Diplomatiques, 192-194; Sturdza, Recueil de documents, 119-122 (Protocol 12, 4 July 1878). 
for the vessels for river police and customs services, as well as the Great Powers' light warships allowed on the Maritime Danube. According to Article 53, the Commission was to include Romania, maintaining its rights, prerogatives and obligations on the section downstream of Galați 'in complete independence of the territorial authority'. A year before the end of its term, member states could discuss its prorogation or other changes in its status (Article 54). The regulations concerning navigation, river police and surveillance for the section between the Iron Gates and Galați were to be drafted by the Commission, assisted by the delegates of riparian powers, and harmonised with those for the section under the direct supervision of the Commission (Article 55). The Commission was to directly administer the functioning of the lighthouse on Serpent Island, and Austria-Hungary was to carry out the Iron Gates works and had the right to levy a tax for covering the expenses incurred by these hydrotechnical programmes (Articles $56-57$ ). ${ }^{27}$

The outcome of the Berlin Treaty in relation to the Danube Question was a reasonable compromise for all interested parties, godfathered by the 'honest broker', Bismarck. Russia reannexed Bessarabia and became riparian to the Danube's northern branch, Chilia. But it refrained from requesting the Danube Delta proper, a territory where the Commission had carried out significant engineering works to the benefit of all European nations. By allowing Romania to acquire the Danube Delta, Russia transferred to the government in Bucharest the task of coping with the presence of an IO that functioned in complete independence of the local territorial authority. The western powers accepted these territorial changes and the guarantees that they had little effect on the preservation of the free navigation principle, embodied by the Commission, the guarantor of Europe's interests in the area. Austria-Hungary managed to remove any form of international control from its territorial waters, upstream of the Iron Gates, and formalised its hegemonic claims over the Iron Gates river section and downstream of it.

\section{5}

\section{The Berlin Congress as a Security Management Institution}

Scholars of the history of international relations and security studies have analysed Europe's Concert of Powers as an international security management institution that facilitated 'a peaceful adaptation to changes in the international system'. It is usually argued that the Concert ended with the Crimean War, but it is safer to say that it lasted throughout the long nineteenth century, at least in

27 The text in Documents Diplomatiques, 291-293; Sturdza, Recueil de documents, 123-124. 
relation to some of Europe's hot issues. The Eastern Question was one of them. As the Near East had great potential to destabilise the entire continent, diplomatic conferences often convened to deal with regional problems in its southeastern periphery: in 1858 to grant the Principalities a constitution, in 1860 to pacify Syria, in 1863 for the Greek succession and annexation of the Ionian Islands, in 1869 for the Greek-Ottoman conflict, in 1871 for the Black Sea navigation, and in 1876 to pacify the Balkans. ${ }^{28}$ In all these instances, the powers followed security procedures designed to maintain order and peace. Beyond their diverging interests, they cooperated well and managed to secure the stability of the area and of the international system. These states also followed explicit rules of behaviour during their conference diplomacy: territorial changes were approved amongst the powers, and the honour and susceptibilities of member states were not to be challenged. Mutual consultation and collective decisionmaking, the creation of buffer states and the clear delineation of interests and of areas of involvement, interventionism by multilateral action, pacific settlement of disputes, communication and the provision of advance notification were among the main procedures followed in dealing with the frail balance of southeastern Europe. ${ }^{29}$

The Berlin Congress was such a security management institution, as Russia was quick to acknowledge, forced by the collective response of the other Great Powers that the San Stefano Peace Treaty was only a preliminary settlement to be negotiated in the Concert for coming to a lasting solution to Europe's general stability. The military conflict itself followed a failed diplomatic attempt in Istanbul, and in the aftermath of the war, Russia resumed diplomatic bargaining with the other powers to resettle a functional balance in the area. The Berlin Congress was preceded by bilateral agreements, and the Great Powers acted as if linked to the system by legal and moral obligations. Eventually, when top diplomats convened together, they negotiated their claims and managed to conclude a reasonable, peaceful settlement.

Such operational rules and behaviour were understood and accepted not only by the Great Powers, but also by lower-tier states. The attitude of Romanian statesmen and public opinion in the Bessarabian/Danube Question is illustrative of this. Romania was itself an offspring of Europe's Concert, and its diplomats understood concessions and compromises were being made to secure

28 Peter Macalister-Smith and Joachim Schwietzke, Diplomatic Conferences and Congresses. A Bibliographical Compendium of State Practice 1642 to 1919 (Graz 2017).

29 Based on Louise Richardson, 'The Concert of Europe and Security Management in the Nineteenth Century,' in Helga Hatendorn, Robert O. Keohane and Celeste A. Wallander (eds.), Imperfect Unions: Security Institutions over Time and Space (Oxford 1999), 48-80. 
Europe's peace. Prince Charles I knew it all too well, ${ }^{30}$ and he often shared his thoughts on the matter with his father and advisor, Prince Karl Anton of Hohenzollern-Sigmaringen, Bismarck's predecessor as Chancellor of Prussia. Romanian statesmen such as Brătianu and Kogălniceanu, both educated in Western Europe, were equally aware of the larger picture of regional and continental interests. What made their assent to the 1878 changes more difficult was the feeling of legal and moral injustice created by the situation of being 'robbed' by a former ally with whom they had concluded an agreement to prevent that very outcome. The loss of Bessarabia was a serious territorial amputation, which the western powers accepted, apparently regretfully, for the sake of Europe's security. They even felt morally obliged to ask for an extension of the territorial compensation granted to Romania in Southern Dobrudja. ${ }^{31}$

All in all, for the Romanians the Berlin Congress was a harsh encounter with Europe's Concert, which had new offspring to take care of. State independence was recognised by several powers, pending the fulfilment of several conditions, including the acceptance of the territorial exchange. Frustration ran high in Romania, but, unjust as it was, the system had allowed the creation and further development of smaller actors surrounded by imperial rivals. In October 1878, the Parliament eventually voted in all necessary legislation, and the Romanian administration withdrew from Bessarabia and took possession of the Danube Delta and Dobrudja.

As Eminescu noted in an article, few things changed for Romania's mission as the guard of the Lower Danube:

Bessarabia was given to us to indicate our role at the mouths of the Danube, and keeping that piece of land was for us a European mission. The same Europe that had given it to us found it appropriate to take it back and gave us Dobrudja, renewing a mandate it had quietly given to us under the Paris Treaty: that of guarding the freedom of the most important artery of Eastern trade, not so much through our own powers, but through the lack of interference of a great power, whatever that would be, whose predominance would become decisive through its exclusive control over the mouths of the Danube. Fated to be the owners of a good which all great powers want to freely use, our weakness is a guarantee. ${ }^{32}$

$30 \quad$ Memoriile Regelui Carol I al României: de un martor ocular, vol. IV, edited by Stelian Neagoe (Bucharest 1994), 127.

31 Documents Diplomatiques, 161-166.

32 Eminescu, Opere, v, 214 (Anexarea Dobrogei, 19 August 1878). 
In the autumn of 1878 , the Commission convened at its headquarters to take cognisance of the alterations in its constitution and jurisdiction, as they resulted from the Berlin Treaty. Updating the Commission's regulations, and mainly its 'Constitution', the 1865 Public Act, had already become imperative, as its decisions were being openly questioned by interested parties. ${ }^{33}$ Despite this apparent sense of urgency, it took delegates and their governments six plenary sessions and more than two-and-a-half years to complete this task. It was eventually done by drafting an Additional Article to the 1865 Public Act, a document signed in Galați on 28 May 1881. Each of its nine articles was the result of complex negotiations both amongst the powers and with the delegates from Romania and Russia, who aimed to limit the Commission's impositions of their territorial sovereignty. ${ }^{34}$

The proposal to secure the Commission's independence came from Austria-Hungary's Haymerle, and was supported by all the Great Powers given the difficulties which the organisation had previously faced in its relations with the 'territorial jealousy' of the Ottoman Empire. Russia was aware that the Commission, an agency of Europe's Concert guaranteed by previous collective treaties, had to be preserved in the Danube Delta, at least until 1883, when its twelve-year-long extension would expire. Russia never openly questioned its existence and rights, and the Commission was the reason Russia did not insist on the return of the Danube Delta, which it had lost in 1856 , at the same time as Southern Bessarabia. The western powers, in their turn, were more than happy to continue with an organisation that, beyond its role in boosting economic prosperity, acted as both actor and arena for mediating political stability in a complicated inter-imperial contact zone.

When granted by the Berlin Congress, this independence was motivated by practical reasons resulting from the effects of the $1877-1878$ war on the Commission (Chapter 4). 'The works and establishments of all kinds' created by the Commission, including its executive agents, were granted 'neutrality' by the 1865 Public Act, which 'in case of war' had to be 'equally respected by all belligerents'. This 'institutional neutrality' was followed by the formal or

33 The National Archives of the United Kingdom, Public Record Office, Foreign Office (hereafter TNA/FO), Fund 881 (Confidential Print. Numerical Series), File 3861, Correspondence Respecting the Execution of the Provisions of the Treaty of Berlin with Regard to the Navigation of the Danube, 1878-1879, f. 1 (No. 1, Herbert Taylor Siborne to the Marquees of Salisbury, Galați, 4 September 1878).

34 The National Archives of Romania, Galați Branch, Protocols of the European Commission of the Danube (hereafter PECD), Appendix to Protocol 384, 28 May 1881. 
informal granting of several privileges which the organisation enjoyed in the port of Sulina and along the Maritime Danube (such as exemption from paying customs dues for the importation of necessary goods for its works or financial autonomy - see Chapter 9). In 1871, at the London ambassadorial conference that dealt with the navigation of the Black Sea, the Commission's 'neutrality' was extended to its 'entire administrative and technical personnel. However, in 1877 , during the Russian-Ottoman war, some of the Commission's agents employed by the Porte by virtue of its territorial sovereignty, violated this provision by supporting their own country. The belligerents conducted naval operations that affected commercial navigation in the area, so European diplomats felt the need to clarify the independent status of the IO. What it actually meant was rather vague according to international law, and it was the task of the eight commissioners to clarify the exact relations between the Commission and its new host state, Romania. ${ }^{35}$

In its 1879 spring session, the Commission discussed and adopted a new Organic Regulation, formulated to adapt its proceedings to a new administrative structure. Commissioners were to rotate as president for one plenary session, a period during which they managed the organisation's activities. The independent regime was legislated in a fully-fledged collegial institution, which replaced the formal Ottoman presidency. Equally, it prevented the rather odd situation of having a delegation of Europe's Concert 'presided over by the delegate of such a small state as Romania.' ${ }^{36}$ Decisions were taken by a majority of votes in matters of form and for changes of the navigation tariff, but unanimity was required for substantive matters. It further settled the attributions of the Executive Committee (which ran the institution between plenary sessions), and the auditing of the Commission's financial proceedings, now done by the employees of the organisation, not by those of the territorial state. ${ }^{37}$

In March 1879, the Romanian cabinet published several regulations detailing the administrative organisation of its newly acquired territories, and disputes of jurisdiction followed in harmonising them with the Commission's rights, privileges and immunities. Serious incidents occurred when Romanian troops,

35 Joseph L. Kunz, 'Privileges and Immunities of International Organizations,' American Journal of International Law 41.4 (October 1947): 828-862; Tiina Pajuste, 'The Evolution of the Concept of Immunity of International Organisations,' East-West Studies 8 (2017): 7-10 (online at http://publications.tlu.ee/index.php/eastwest/article/viewFile/641/486, visited on 15 August 2018).

36 TNA, FO 881/3861, Correspondence, f. 4 (Inclosure 1 to no. 3, John Stokes to Salisbury, Chatham, 22 October 1878).

37 PECD, Protocols $324-326$ and $328-329,13,14$ and 20 May 1879. It was voted for on 10 November 1879 (Protocol 337, also in Sturdza, Recueil de documents, 127-135). 
dispatched to maintain peace and order in Sulina, were themselves the cause of local instability. On 11 May 1879, armed soldiers boarded a British steamer, the Dilston Castle, and prevented its crew from completing the loading of cargo in the vessel's hold. On 6 June, a Romanian guard shot in the direction of a Russian boat, and three days later a Greek sailor was wounded in a similar incident. Moreover, shipping was forbidden in the port after eight o'clock in the evening, a decision that greatly hindered the economic life of a busy harbour. Discussed in the Commission, these incidents were considered 'an attack on the freedom of navigation' and a violation of the organisation's attributions in securing the policing of navigation on the Maritime Danube. ${ }^{38}$ A Romanian investigation ensued and the officer responsible was dismissed. Furthermore, the government in Bucharest pledged to restructure local administration so as to maintain tranquillity in the town, but at the same time prevent any further disputes with the Commission. ${ }^{39}$

Such problems were caused by Romania's plan to appoint a harbour master at Sulina, a right it claimed that the Ottoman Porte had previously enjoyed. However, the Commission insisted on its total independence from the territorial authority. ${ }^{40}$ Romania's opposition was unsuccessful, and eventually the Commission imposed its right of appointing, dismissing and remunerating the Commission's executive agents (the Sulina Harbour Master and the Inspector General of Navigation). These employees were also judges of first instance for offences committed in relation to the policing of navigation, and their sentences were given on behalf of the Commission.

Sulina's 'exceptional status' was equally visible in relation to its fiscal facilities. Romania was trying to impose its new administration in the Danube Delta, but the stipulations of its new economic policy infringed upon the Commission's privileges. These included exemptions from paying customs and municipal dues at Sulina, and exemption of customs dues in the ports along its jurisdiction for the importation of materials and goods needed for the organisation's hydraulic works. The Commission enjoyed full possession of the estates it used for its works and administrative services, was exempted from paying taxes for these estates, and paid only a symbolic contribution as mentioned in the 1865 Public Act. It could use the stone quarries of Tulcea and Isaccea and benefited from postal and telegraphic exemptions for its official

$38 \quad$ PECD, Protocol 333, 13 June 1879.

39 Ibid., Protocol 336, 28 June 1879. Some details in Ana Maria Cheșcu, 'Afacerea de la Sulina (1879),' Studii și articole 1.1 (2016): 11-12.

$40 \quad$ PECD, Protocol 340, 21 November 1879. 
communications.${ }^{41}$ Such privileges were not limited to the organisation's staff or possessions, as the entire town of Sulina was a free port where goods were not taxed. When the Romanian authorities tried to impose customs dues at Sulina, the price of coal and provisions increased by 60 per cent, to the economic detriment of thousands of international ships that called there every year. ${ }^{42}$ After long negotiations, the Romanian government agreed to grant tax exemption for all products required by the Commission and its technical works, and a similar privilege was extended to employees of the organisation in Sulina (see Chapter 9).

By virtue of its complete independence, the Commission took upon itself the administration and maintenance of the lighthouses that formed the lighting system at the mouths of the Danube. This decision was motivated by the financial benefits of direct administration, resulting from a long dispute with the company that managed the lighthouses in the Ottoman Empire. ${ }^{43}$

Equally vital for a proper balance between public safety and free navigation was the settlement of quarantine procedures at the Lower Danube, an area often stricken by deadly epidemics of cholera. According to the final agreement concluded between Romania and the Commission, health regulations were to be developed and modified by an International Health Council established in Bucharest. This institution was to decide on the appointment and remuneration of health personnel, the installation and operation of its offices, the establishment and maintenance of a lazaretto, methods of collecting sanitary taxes and the destination of this income.

Another provision of the 1881 Additional Article concerned the Commission's flag, a marker of the organisation's neutrality and full independence (see Fig. 15). For many years the Commission had been using a special signal flag for its fleet of ships. The Porte had accepted it on condition that pilot or police vessels also flew the Ottoman flag. This had been inconvenient during the 1877-1878 war, when the Commission pledged its complete neutrality. ${ }^{44}$

All these rights, privileges and immunities turned the Commission into a rather unique organisation in the latter half of the nineteenth century. It had acquired an exceptional status in the attempt to compensate for the limits of its host state, which did not possess the human resources and technical means to conduct the hydraulic and administrative works necessary to secure free

\footnotetext{
41 Ibid., Protocol 348, 15 December 1879.

42 TNA, FO 881/3861, Correspondence, f. $5^{8}$ (No. 40, Siborne to Salisbury, Thames Ditton, 13 January 1879).

43 La Commission Européenne du Danube et son œuvre de 1856 à 1931 (Paris 1931), 319-323.

44 TNA, FO 881/3861, Correspondence, f. 4 (Inclosure 1 to No. 3, Stokes to Salisbury, Chatham, 22 October 1878).
} 


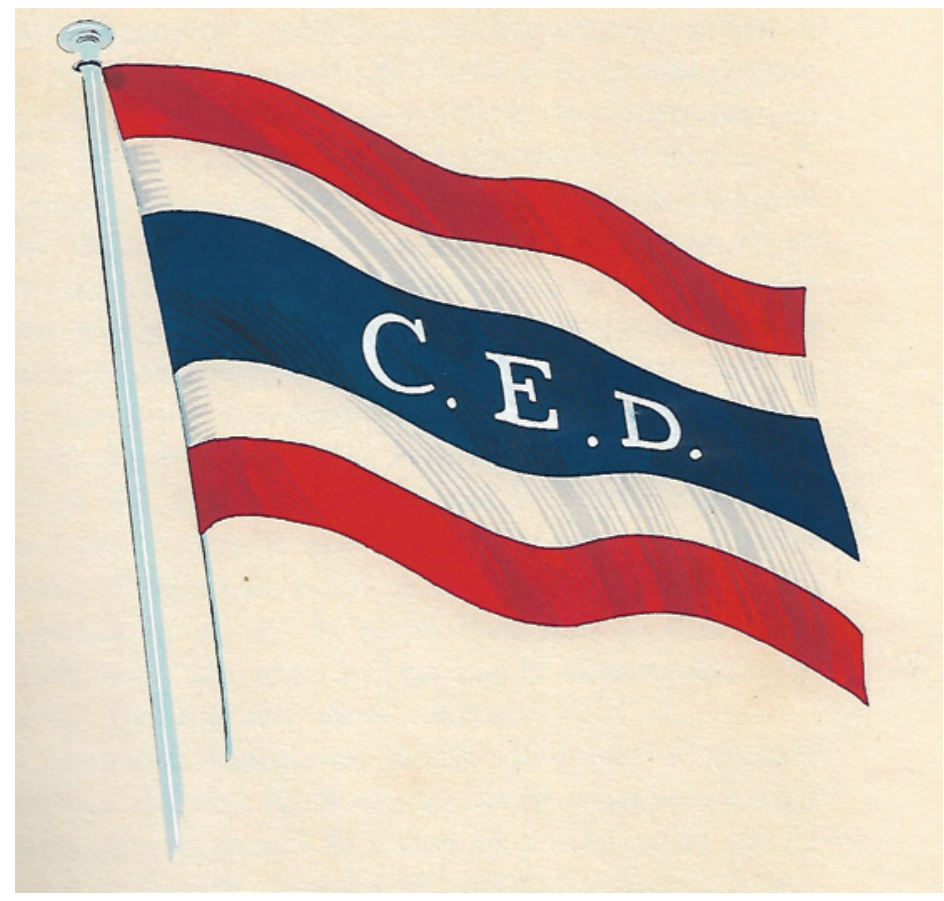

FIGURE 15 Flag of the European Commission of the Danube SOURCE: THE NATIONAL ARCHIVES OF ROMANIA, GALAT, I BRANCH

and safe navigation for all interested nations. Political considerations were equally important, and this independence was a further guarantee for completing the organisation's mission to secure the political stability of an interimperial contact zone. The Commission could not prevent war in 1877-1878, but the presence of international employees in Sulina had reduced the usual destruction caused during previous conflicts.

The Commission understood its status as not only providing legal and practical guarantees which allowed it to fulfil its task, but also as acting independently of Romania's sovereign rights. With so many rights and immunities along the Maritime Danube and in its 'internationalised headquarters' at Sulina, the Commission took independence in a territorial sense and acted as a full person in international law, endowed with a form of statehood over its jurisdictional territory. A weak state at the beginnings of its independent existence, Romania accepted this violation of its national sovereignty given the Commission's role in limiting the hydro-hegemonic claims of neighbouring empires. Already in 1883, a Romanian statesman and former prime minister of 
the country, Dimitrie Brătianu, noted that the Commission was a state within a state. The positive part was that 'at least the river is not under an exclusive domination, but under that of the whole of Europe. 45

With growing nationalism in the early twentieth century and the development of Romania's abilities to better administer Danubian navigation, this became a topic of continuous conflict between the government in Bucharest and the Commission. In 1927, a dispute between the two parties was judged by the International Court of Justice in The Hague. The case presented was 'the particular territorial competence of an institution charged with managing the uses of an international river'. The Court ruled that although the Commission exercised its functions in complete independence of the territorial authority, it was not 'an organisation possessing exclusive territorial sovereignty'. As it was not 'a state, but an international institution with a special purpose, it only has the functions bestowed upon it [...] with a view to the fulfilment of that purpose, but it has the power to exercise those functions to their full extent, in so far as the [instrument] does not impose restrictions upon it. ${ }^{46}$ The question returned to the agenda of member states in the pre- and post-World War Two context, and its solution was yet another complicated question related to the political fate of southeastern Europe (see Chapter 10).

In 1881 the Commission concluded a process that had continued for the preceding 25 years - supplying itself with attributions that would allow it to fulfil its task. Its hydraulic programme had proved impossible to accomplish without financial and administrative prerogatives, which in turn had directed the early commissioners to look for legislative, executive and juridical powers to regulate navigation on the Maritime Danube. The ${ }^{8} 865$ Public Act marked the Porte's agreement to trade sovereignty in exchange for increased functionality. With Russia's remilitarisation of the Black Sea in 1871 and return to the Danube in 1878 , the Commission also assumed an important political role, as a collective European bulwark in a disputed borderland. The IO was regarded as the creation of Europe's Concert, an offspring born in the aftermath of an interimperial conflict and collectively nourished by its seven creators. It violated in many ways the sovereignty of a young state, but it also helped it cope with the perils posed by its greater imperial neighbours.

$45 \quad$ Națiunea, 2:183 (30 January 1883): 1.

46 Summaries of Judgments, Advisory Opinions and Orders of the Permanent Court of International Justice (New York 2012), 116-132; detailed discussions in Répertoire des décisions et documents de la Cour de La Haye, série I, Cour permanente de justice internationale 1922-1945, vol. IV, Les compétences de l'État, edited by Peter Haggenmacher and Richard Perruchoud (Geneva 2004). 


\section{'The Freedom of the Danube Is a Key Condition for the Political and Economic Development of Riparian States'}

On 27 November 1881, King Charles I presented his message at the opening session of the Romanian Parliament. It was his first address after Charles' festive crowning as King of Romania on 22 May, exactly fifteen years after his arrival in Bucharest. His reign had not been smooth, and he had many moments of despair and frustration with Romanian politics and mores. But with his brave attitude during Romania's Independence War and in the ensuing Bessarabian crisis, he was regarded as a great statesman, a perfect embodiment of German seriousness and rigour transferred to southeastern Europe. The year 1881 had been complicated, dominated by political disputes within the governing liberal factions and by diplomatic efforts to secure the international recognition of Romania's royal status. But the Danube Question was the main topic on the political and public agenda, and Charles I chose to tackle it directly in his address, as shown in the sub-heading above and quote below:

The Romanians have always expressed their gratitude to those who have contributed to the freedom of this river from any exclusive preponderance. The freedom of the Danube is a key condition for the political and economic development of riparian states. [...] We do not want to harm anyone. But we want, we are obliged and we want the absolute freedom of the Danube, at least in our waters, and we are ready, now as in the future, to make any necessary sacrifice for ensuring the absolute freedom of navigation for everyone. ${ }^{47}$

The royal message was, from several perspectives, unusual. It was full of direct references to Austria-Hungary, whose hegemonic economic policies Romania was criticising at its highest political level. By the mid-1870s, while in search of state independence, the conservative government in Bucharest had concluded a commercial agreement with the Viennese cabinet in highly advantageous conditions for the much larger and industrialised imperial economy. Romania had virtually become an economic dependency of the double monarchy, with about half of imports coming from the empire, and a third of its exports going in the same direction. ${ }^{48}$ After 1878 , liberal forces aimed to provide the country

47 Cuvântările Regelui Carol I, vol. I, 1866-1886, edited by Constantin C. Giurescu (Bucharest 1939), 372-380.

48 Șerban Rădulescu-Zoner, Dunărea, Marea Neagră și Puterile Centrale 1878-1898 (ClujNapoca 1982), 32-87. 
not only with political independence, but also economic freedom. The early buds of economic protectionism date from that period. The economic pressure coming from the double monarchy, visible in blocking Romania's land trading routes under pretences such as epizooty, had turned the Danube into a vital resource for the country's economy, and free navigation for all flags was a way of preserving independence from an exclusive Austrian-Hungarian hegemony. The intention of the Viennese cabinet to secure its control over an important section of the river, the Iron Gates-Galați stretch, was seen as part of Vienna's plans to completely subjugate the country.

The royal address was hailed in both chambers of the Parliament. Romania owed its political existence and economic prosperity to the Danube, and free navigation was the strongest guarantee for its future. The Chamber of Deputies pledged to support the government and 'protect the freedom of the Danube and Romania's sovereign rights from any prejudice, according to European public law' ${ }^{49}$ The Senate came up with a similar motion, ${ }^{50}$ but it was the reply from the conservative opposition, read by Petre P. Carp, that is worth mentioning.

Carp had studied literature, politics and law at the universities of Berlin and Bonn, and was considered one of the brightest minds of Junimea, Romania's most influential intellectual circle of the 1860s-1870s. Together with several colleagues, Carp had joined the conservative group in Bucharest, and imposed himself as a gifted realist. In 1881, he contended that, in the Danube Question, the liberal government had blended popular emotions with reason. In dealing with such sensitive issues, absolute tranquillity and confidentiality were required, and passions had to be put aside. With the press reporting daily on Danubian affairs, and with both politicians and the larger public greatly aroused on the issue, 'the passionate movement of the masses can only be satisfied with diplomatic success or, in case of failure, with war'. Carp shared similar views on the Danube's importance, but this very relevance compelled the country and its leaders to be ready to make sacrifices for its defence: 'Let us sacrifice some of our sovereign rights to obtain the protection of the entire Europe and not be isolated from two powerful neighbours. And perhaps by stripping off part of our sovereignty, we will be stronger than by keeping a harmful pride. What Carp envisaged was a temporal and geographical extension of the Commission's term beyond 1883, but his response was a clear message for political pragmatism and the need for bargaining. ${ }^{51}$

49 'Proiect de răspuns la discursul Tronului,' Românul, 2 December 1881.

5o The debates in Constantin I. Băicoianu, Dunărea. Privire istorică, economică și politică (Bucharest 1915), appendix XVIII, 243-280.

51 Petre P. Carp, Discursuri parlamentare, edited by Marcel Duță (Bucharest 2000), 136-137. 
The royal message had a huge impact both on Romanian and international politics, and public opinion. The Viennese cabinet instructed its minister in Bucharest to break off diplomatic relations with Romania, and in Vienna and Budapest several newspapers launched a strong campaign against 'Romanian chauvinism'. Meanwhile, Charles I was hailed in Romania as a true patriot who took a public stand against the enemies of the state and nation. With millions of ethnic Romanians living in Austria-Hungary, the Danube Question added to the wounds of the 'national question', the growing alarm caused by the fate of the 'Transylvanian brethren' exploited in the Double Monarchy.

\section{The Fluvial Danube - between Austrian Hydro-imperialism and European Multilateralism}

The dispute between Romania and Austria-Hungary over the Danube Question was not new, and readers will be taken back in time to its origins. It had started in 1879, when the Viennese cabinet launched diplomatic negotiations with the view of applying Article 55 of the Berlin Treaty. This stipulated that the regulation concerning navigation, river police and surveillance for the Iron Gates-Galați section of the Danube was to be drafted by the Commission, assisted by delegates of riparian powers, and harmonised with those valid for the river section under the Commission's direct jurisdiction.

The Austrian-Hungarian statesmen proposed creating not just legislative instruments applicable to the Fluvial Danube, but also designed the executive body that was to impose them. The best way to secure this superintendence was to create a sub-commission or an inspectorate composed of representatives of the three riparian states (Serbia, Bulgaria and Romania), led by an Austrian president. ${ }^{52}$ The Viennese statesmen thought that it was 'not advisable to intrust the three states conterminous to the river the exclusive right of supervision, as practically they would then have to superintend themselves; on the other hand, it would be difficult to exclude them altogether'. The best plan was to create this separate organisation, presided over by the Viennese delegate, whose presence would provide a guarantee for the supervision being 'real and effectual. ${ }^{53}$ The solution went somewhat beyond the Berlin Treaty terms, and aimed to secure the Double Monarchy's control over a river section beyond its territorial reach, where it had vital economic interests to defend.

\footnotetext{
52 TNA, FO 881/4301, f. 71-72 (No. 43, Edwin H. Egerton to Salisbury, Vienna, 18 September 1879).

53 Ibid., f. 86-88 (No. $5^{2}$ and inclosures, Count Alajos Károlyi to Salisbury, London, 21 October 1879).
} 
The proposal was communicated to interested governments, which seemed willing to accept the Inspectorate as a temporary measure. ${ }^{54}$ During its 17 December 1879 sitting, the Commission agreed to set up a committee (composed of the delegates of Austria-Hungary, Germany and Italy), which was to draw up a preliminary draft of the regulations mentioned in Article $55 .{ }^{55}$ The draft, completed in May 1880, stipulated the creation of the new organ, dubbed the Mixed Commission of the Lower Danube (MCLD), an agency with its headquarters in Ruse, Bulgaria, halfway along the Lower Danube. It was made up of four commissioners, three local ones and an Austrian-Hungarian delegate, who served as president and had a casting vote in case of equal votes. The MCLD was to have large attributions, influenced by the Commission's own status: navigation and port officials in riparian countries were its subordinates, and it approved the construction of public works which could affect river navigation. It was also loosely connected with the Commission, which was to judge in final instance disputes and complaints regarding navigation. ${ }^{56}$

The Berlin Treaty had recognised Vienna's vital interests in carrying out hydraulic works for the improvement of the Iron Gates (i.e. beyond its territorial reach), where riparian states had to give it every necessary facility. This was not dissimilar to how the western powers had used their economic and political interests to justify the creation of an extraordinary regime at the Maritime Danube, embodied by the Commission. With major economic stakes at the Iron Gates, Austria-Hungary bargained for a similar recognition of its interests and, in 1871, gained the right to improve the Iron Gates, further confirmed at Berlin in 1878. In 1879, based on a similar argument, it requested from Europe's Concert acceptance to extend this privileged economic space to the rest of the Lower Danube, downstream all the way to Galați, wherefrom the Commission imposed its own jurisdiction. ${ }^{57}$ To Vienna and Budapest, the Lower Danube was a corridor of imperial expansion and hydro-capitalism, like the railways through which the monarchy pushed its economic interests in the area. ${ }^{58}$

54 Ibid., f. 95-96 (No. 70, Salisbury to Károlyi, London, 1 November 1879 and No. 71, Odo Russell to Salisbury, Berlin, 30 October 1879).

55 PECD, Protocol 349, 17 December 1879.

56 Cestiunea Dunării. Acte și documente (Bucharest 1883), 570-583.

57 The Viennese Foreign Office accepted this solution after disputes with the representatives of the local Board of Trade - details in Emil Palotás, 'The Problems of International Navigation on the Danube in Austro-Hungarian Politics during the Second Half of the Nineteenth Century,' in: Southeast European Maritime Commerce and Naval Policies from the Mid-Eighteenth Century to 1914, edited by Apostolos E. Vacalopoulos, Constantinos D. Svolopoulos and Béla K. Király (Boulder and Highland Lakes 1988), 104-106.

$5^{8}$ Gerhard Rosegger and John H. Jensen. 'Transylvanian Railways and Access to the Lower Danube, 1856-1914,' East European Quarterly 29.4 (1995): 427-448; Lauren Benton, A Search for Sovereignty: Law and Geography in European Empires, 1400-1900 (Cambridge 
Two opposing visions on the role of commerce collided in the dispute between Austria-Hungary and Romania. For the Viennese statesmen, extending imperial control over the fluvial section was a civilising and moralising mission, like that pursued by other empires in their extra-European colonies. The Danube was the natural way to spread wealth and civilisation to backward territories, which already orbited around the industrialised imperial core. There were political reasons for this, too, as closer economic ties with neighbouring nation-states could reduce disparities and secure both prosperity and security in the empire's borderlands. Economic imperialism and the establishment of 'commercial colonies' in Europe's southeastern periphery was a way of turning states such as Serbia and Romania into stronger actors in complicated interimperial areas. The Danube needed hydraulic works, but also legislative and executive mechanisms beneficial not only for Vienna, but also for these small and weak states, which did not have the human and material resources to conclude such modernising programmes.

In Romania, such plans were analysed through colonial lenses. The cabinet had long fought for state independence and for having its full sovereignty recognised by Europe's Concert. Several remnants of foreign intervention were preserved in the Berlin Treaty in relation to the Jewish minority and to consular jurisdiction, but the nation was ready to claim its full independence. Romania owed its very existence to Western Europe's interests in having unobstructed access to a rich granary, and agricultural goods stood at the basis of its current prosperity. Economic nationalism gradually made its way into governmental programmes, but it came with sincere internationalism and openness in the country's foreign trade. It was vital for Romania to rely on free navigation in exporting its rich raw output, and the Danube was Romania's only natural waterway. In 1878, the seaport of Constanța in Dobrudja was granted to Romania, and this opened new perspectives of development, though at the time the new province was not connected to the Romanian mainland. ${ }^{59}$ If, on the Viennese side, imperial economics was used to advance economic interests downstream of its territorial reach, on the Bucharest one defending a non-hegemonic, collective and international economic environment was part of the country's plan for preserving state independence.

2010); Pritchard, 'From Hydroimperialism to Hydrocapitalism: 'French' Hydraulics in France, North Africa, and Beyond,' Social Studies of Science 42.4 (2012): 591-615. 


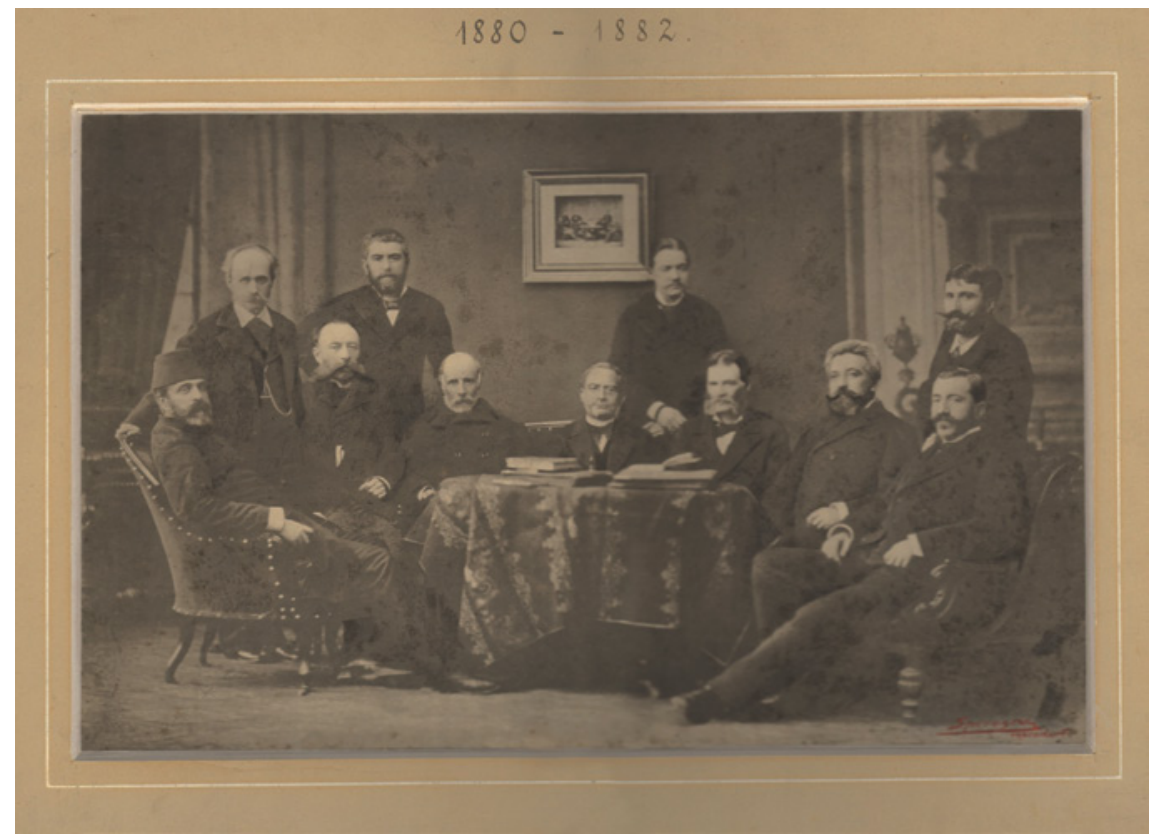

FIGURE 16 Group photo of the Danubian Commissioners (1882)

SOURCE: THE NATIONAL ARCHIVES OF ROMANIA, GALAȚI BRANCH

In its June 1880 sessions, the Commission analysed the draft that envisaged the creation of the MCLD, and the IO soon became an arena of intense diplomatic negotiations. ${ }^{60}$ What further complicated things was the provision to invite delegates of riverbank states. Based on the decision of interested governments, Serbia and Bulgaria were invited to have a deliberative voice, as resulting regulations were to become part of their national legislation. ${ }^{61}$ Giving equal voice to three new states (Romania, Serbia and Bulgaria, the latter not even a sovereign state) in an organism that represented Europe's Concert was an interesting and rather unique experiment at that time. And their silenced voices were soon to be heard loud and clear.

To the Romanians, the draft proposal contained 'symptomatic similarities' with the 1857 Navigation Act of the Riparian Commission, a document strongly opposed at the time by the western powers. Statesmen were, however, divided in their opinions and readiness for negotiations. During a visit to Berlin,

6o PECD, Protocol 364, 4 and 7 June 1880.

61 TNA, FO 881/3861, f. 248-249 (No. 194, Memorandum of Károlyi communicated to Granville, London, 4 May 1880). 
Charles I was advised to come to terms with the Viennese project and conclude an agreement that was more remunerative for Romania's interests. Diplomats were advised to stay on the defensive and be ready to bargain, but Romania's more radical and nationalist ambassadors protested against this conciliatory policy of Foreign Minister Vasile Boerescu and demanded to openly resist Austria-Hungary's claims. In London, Nicolae Callimachi-Catargiu violently attacked Vienna's plans for economic and political hegemony, while in Paris Kogălniceanu was equally aggressive in making clear Romania's vital interests in the Danube Question:

We have plenty of goodwill, we feel all the need to have good relations with the Austro-Hungarian Empire. We very much value the goodwill of the Imperial-Royal government, but our rights, our interests, and our future do not allow us to accept a foreign hegemony in our waters! With all our desire to maintain close and neighbourly relations with the Viennese Court, we cannot give in in this matter! [emphasis in original] ${ }^{62}$

The discourse of 1878 returned, with Russia replaced by Austria-Hungary as the imperial threat. The country was under assault, and it had to defend its sovereign rights. As the Viennese cabinet enjoyed the support of its allies, Germany and Italy, Romania needed to rely on Britain and France, and use the Commission as the guardian of Europe's interests. The Danube Question was inflated by the press, with both governmental and opposition papers insisting on the leitmotif that the 'freedom of the Danube is an indispensable condition for Romania's very existence. The story of a small nation confronted with the hegemonic ambitions of an imperial neighbour was rewritten, with the hope that this time the country's moral and juridical rights would prevail.

Discussions on the project continued in the autumn and spring sessions of $1880-1881 .{ }^{63}$ The Viennese government negotiated a compromise with the Great Powers and agreed to include in the regulation clearer references to the freedom of navigation and to the Commission's role as mediator between Europe's interests and the MCLD, which it considered reasonable to control. Western non-riparian states accepted the creation of the MCLD and Austria-Hungary's chairmanship, but by coupling it institutionally and

\footnotetext{
62 Mihail Kogălniceanu, Cestiunea Dunării (Bucharest 1882), 85.

$63 \mathrm{PECD}$, Elaboration des règlements prévus par l'article 55 du Traité de Berlin pour la partie du fleuve compris entre les Portes de Fer et Galatz, Protocols 1 to 20, 4 December 1880 to 21 June 1881.
} 
temporarily to the Commission they aimed at strengthening the latter organisation, whose term was due to expire in April $1883 .{ }^{64}$

By early 1881 , defending the Danube was Romania's most pressing political priority, and Eustațiu Pencovici (1836-1899), its commissioner since 1879, was busily fighting for the country's rights. After graduating from military school, he had pursued a career in the Romanian army, which brought him to the rank of colonel. But his greatest fight was that of defending his country's sovereign rights, a struggle that was closely followed and inflated by the press. One of Pencovici's strategies was to seek the cooperation of the delegates of the other two small riparian states, Serbia and Bulgaria. The Serbian agent, Alexander Nicolić, consulted with his Romanian counterpart, and the Bulgarian delegate, Kiril Zankov, was allegedly secretly instructed to vote for the Romanian proposal. ${ }^{65}$ But this entente between three of Europe's silenced diplomatic voices was only an apparent one, as the cabinets in Belgrade and Sofia were more willing to accept Vienna's (and Europe's) proposal in exchange for concessions in other issues.

A political crisis followed in Bucharest in early 1881 with the resignation of Prime Minister Brătianu. Although other reasons had been decisive, the Danube Question played an important part in this, allowing the new cabinet to distance itself from the too conciliatory Boerescu. Discussed in the Parliament in May 1881, the issue added new divisions not only with the conservative opposition, but also within the ruling liberal coalition. In such circumstances, the new cabinet resisted for only a couple of months before making room for the return of the radical liberals led by the same able politician, Ion C. Brătianu. A new scandal followed in the autumn of 1881 , by the time of the royal address, when Callimachi-Catargiu, dismissed from his ambassadorial position and accused of not defending the country's interests, published a brochure containing his confidential correspondence with the Romanian Foreign Office and blaming the government's treasonous conciliation. ${ }^{66}$

Negotiations in the Commission had also reached a dead end, so by the autumn of 1881 French commissioner Camille Barrère assumed, with

64 TNA, FO 881/4495, f. 1-7 (Memorandum respecting Negotiations with Austria-Hungary relative to Regulations for Danube between the Iron Gates and Galatz, drafted by F.L. Bertie, 7 September 1881, London).

65 Nicolae Dașcovici, Dunărea noastră. O scurtă expunere până la zi a problemei dunărene, însoțită de textul Statutului de la Paris din anul 1921 (Bucharest 1922), 41; more on Bulgaria in Virginia Statelova, 'La Bulgarie et le problème danubienne (1879-1883),' Études Historiques 6 (1973): 189-206.

66 Constantin Bacalbașa, Bucureștii de altădată, vol. I, 1871-1884 (Bucharest 1927), 263-264, $273^{-274}$. 
Austria-Hungary's blessing, the main role in finding a compromise within Europe's Concert. ${ }^{67}$ Negotiations followed in the triangle between Barrère, Percy Sanderson (Britain's new delegate to the Commission) and Count Georg Wolkenstein (a special diplomatic envoy of the Viennese Foreign Office). Eventually, interested governments accepted the so-called Barrère solution. ${ }^{68}$ Its main component was a new structure for the MCLD, which had four permanent members (Romania, Bulgaria, Serbia and Austria-Hungary), and a fifth one was delegated alphabetically by the member states represented in the Commission. This solved the problem of parity of votes and Vienna's casting vote, while the presence of a Commission delegate was likely to contribute to the uniform application of navigation provisions by both organisations. Austria-Hungary had the permanent presidency, and the Commission was to approve the MCLD's regulations, but they were to be applied by agents appointed by the latter institution. The duration of both commissions was tied, and the Commission was to extend its jurisdictions upstream from Galați to Brăila, the terminus of maritime navigation. ${ }^{69}$

The French project aroused the fury of Romanian politicians and public opinion. The same aggressive Kogălniceanu filed a motion in the Parliament and insisted on defending the country's sovereign rights. Stormy debates followed, but to no avail. ${ }^{70}$ Romania came up with a new counterproposal: the regulation should be drafted by the Commission, its execution granted to riparian states, and supervision given to a delegate of the Commission. The MCLD was to consist of the three riparian countries, plus two delegates appointed by the Commission, the only form of IO the country could accept. ${ }^{71}$ In early June 1882, the French proposal was approved by a majority vote in the Commission, despite stubborn opposition from Romania and Bulgaria, and objections from Russia. ${ }^{72}$ However, by now, Romania was isolated diplomatically and in open conflict with Europe's Concert. The government was aware that it had to negotiate, but again public pressure made compromises more difficult to conclude.

67 TNA, FO 881/4596, f. 87 (No. 20 and inclosures, F.O. Adams to Granville, Paris, 3 September 1881).

68 Ibid., FO 881/4742, f. 30-33 (No. 42 and inclosures, F.R. Plunkett to Granville, Paris, 24 March 1882); more with details from Barrère's correspondence in 1881 and 1882 at Centre des Archives diplomatiques de la Courneuve, Commission Européenne de Danube, Files 184 and 185 .

69 Cestiunea Dunării. Acte și documente, 775-780; Sturdza, Recueil de documents, 204-212 (Baron M.N. de Ring to Eugen Stătescu, Bucharest, 17 April 1882).

70 Băicoianu, Dunărea, appendix XVIII, 280-350.

71 Sturdza, Recueil de documents, 237-246.

72 PECD, Elaboration des règlements, Protocol 24 (2 June 1882). 
By 1882, although about to expire in April 1883, the Commission's prestige strengthened following developments in the Danube Question. It had gradually turned from a technical organisation that had accomplished an impressive engineering and administrative programme into a political thermostat able to contribute to the stability and security of the Lower Danube and of Europe. Its attributions had been further consolidated by the approval of the Additional Act in May 1881, when its independent status became fully operational. It did so through negotiations between interested governments, but mainly through the pro-active involvement of commissioners themselves, who understood the benefits for regional security of such an IO.

With significant rearrangements in Europe's political and military alliances in the late 1870 s and early 188 os, the Commission was a diplomatic arena in which Europe's powers tested the solidity of their agreements and facilitated a peaceful adaptation to changes in the international system. Beyond their diverging interests, the Great Powers cooperated well and managed to use the Commission as one of the valves for balancing the international system. Linked by a network of legal and moral obligations, the Commission was an embodiment of Europe's striving for stability. Austria-Hungary and Russia were the powers most interested in the region, and they negotiated compromises in other disputes such as the Egyptian and Tunisian crises, which interested Britain and France to a very great degree.$^{73}$ Barrère's commitment to finding a solution is illustrative of the Congress's functionality, although it is fair to add that France followed its own interests by acting as a political go-between.

\section{The 1883 London Danubian Conference - a Story of Inclusion/ Exclusion}

In accordance with Article 54 of the Berlin Treaty, the western cabinets took the initiative to summon a conference and conclude an agreement for the extension of the Commission's term, due to expire in April 1883. ${ }^{74}$ The conference was to convene in London in early 1883 , and one of the major issues to be decided was the participation of the small riparian states. The case of Romania was the most complex one. Was Romania to have a voice in Europe's Concert,

73 Armand Levy, Comment la liberté du Danube est un question européenne, in: La Roumanie et la liberté du Danube (Paris 1883), XXI-XXIV.

74 Cestiunea Dunării. Acte și documente, 828-829; Sturdza, Recueil de documents, 261-262 (Granville to Lord Lyons, London, 28 October 1882). 
considering its Commission membership, or was the conference reserved to the signatory powers of the 1878 Berlin Treaty?

Romanian diplomats lobbied to be accepted into the London conference. The official position, as presented by Foreign Minister Dimitrie A. Sturdza, was that since Romania was a member of the Commission, it could not be excluded from a conference 'convened to determine the existence and organisation of the institution itself'. Legally, its participation resulted from the provisions of the 1818 Aix-la-Chapelle Congress, when the Great Powers stated that if a meeting of Europe's Concert would be of special concern for other states, their decisions would become compulsory only if those countries took part at that conference. ${ }^{75}$ However, several governments objected to inviting Romania to have a deliberative vote, as the small state had proven to be a trouble-maker. Giving it an equal vote with Europe's Great Powers could prevent a unanimous agreement of cabinets, and thus ruin the meeting's peaceful outcomes. Serbia and Bulgaria had similar claims, simplified by the fact that they were not members of the Commission, and, in the Bulgarian case, that it was still a vassal state.

The London Conference opened on 8 February 1883, after preliminary bargaining on the most important issues. ${ }^{76}$ The agenda included three points: the extension of the Commission's jurisdiction to Brăila, sanctioning the regulations drafted under Article 55 of the Berlin Treaty (i.e. the MCLD), and extending the term of the Commission beyond April $1883 .{ }^{77}$ The admission of Romania and Serbia was discussed two days later. The decision was to invite them with a consultative vote, as the conference declared itself to be a continuation of the 1878 Berlin Congress. Bulgaria was to be notified of decisions through the Ottoman ambassador to London, on behalf of the Ottoman Porte, its lawful sovereign. ${ }^{78}$

The participants agreed to extend the Commission's powers upstream to Brăila, thus including the entire section of the Maritime Danube under its jurisdiction. As Romania was the only riparian country on both banks of the river, it was a new breach of its territorial sovereignty. The river regulations drafted under Article 55 were equally confirmed, and the Austrian-Hungarian

75 Sturdza, Recueil de documents, 275-283 (Sturdza to Romania's diplomatic agents, 9 and 10 December 1882).

76 Leo Andrew Maher, Great Britain and the International Control of the Danube, 1856-1883: A Study of British Policy in South-East Europe with Particular Reference to the European Commission of the Danube, $\mathrm{PhD}$ dissertation, University of Oxford (Oxford 1968), 149-173.

77 Navigation du Danube. Conférence et Traité de Londres. Février-Mars $188_{3}$ (Paris 1883), 5.

78 Ibid., 11-13 (Protocol 2, 10 February 1883); Illhan Ekinci, Tuna Komisyonu ve Tuna'da Ticaret (1856-1883), PhD dissertation, University of Samsun (Samsun 1998), 206-211. 
plenipotentiary announced that his country would make further concessions to secure the acceptance of the MCLD by riparian states. Vienna waived its double vote, provided Bucharest reciprocated (when the Commission's delegate was an Austrian-Hungarian/Romanian diplomat), and accepted the appointment of commissioners as proposed by Romania and Bulgaria. ${ }^{79} \mathrm{~A}$ couple of weeks later, Vienna made further concessions, proving its desire to come to terms with the smaller riparian countries. ${ }^{80}$

The conference later debated the issue of extending the Commission's term. In principle, all powers agreed to the prolongation, but Russia's plenipotentiary, Baron Arthur von Mohrenheim, only consented on condition that the Concert accepted the special status of the Chilia branch, which Russia had bordered since 1878 . As early as 1879 , Russia's Danube commissioner had attempted to remove that river branch from the Commission's jurisdiction. According to the Russian interpretation, as the organisation had focused its hydrotechnical works on the Sulina branch, Chilia was abandoned and the Commission had lost its rights over the northern part of the Danube Delta. Russia resumed its claims in 1882, when the imperial government planned to conduct a scientific and technical study of the Chilia sub-delta, a survey coordinated by Russian experts who were to act independently of the Commission. ${ }^{81}$ In London, Mohrenheim requested a special status for Chilia, and the western powers negotiated a compromise. Eventually, it was agreed that navigation regulations for the Chilia arm had to be based on those drafted by the Commission, but they were applied by the riparian states themselves, not by the Commission. Local states had to notify the organisation if they planned any engineering works and state how this influenced the overall hydrology of the Lower Danube. The compromise was to have Chilia as Russian territory with European legislation. ${ }^{82}$ Once this was agreed, the Commission's term was prolonged for 21 years, at the end of which the IO was to be extended every three years by tacit consent, until one of the signatory powers demanded termination. ${ }^{83}$ This never happened and the Commission continued as such into the First World War.

\footnotetext{
79 Navigation du Danube, 14-17, 25 (Protocols 2 and 3, 10 and 13 February 1883).

80 Cestiunea Dunării. Acte și documente, 841-845.

81 Focas, The Lower Danube River, 377-379.

82 Ștefan Stanciu, România și Comisia Europeană a Dunării. Diplomație. Suveranitate. Cooperare internațională (Galați 2002), 136; Russia's diplomatic efforts in 1883 are detailed in Maher, Great Britain, 166-172.

83 Navigation du Danube, 51; Sturdza, Recueil de documents, 458-46o (Protocol 6, 1 March 1883).
} 
The London Treaty was signed on 10 March $1883^{84}$ and the European press, which followed the proceedings closely, considered it a triumph of international compromise, in which Britain secured its control over the Suez Canal by allowing Austria-Hungary and Russia to satisfy their interests on the Lower Danube. With Europe's imperial powers concluding an advantageous agreement to the detriment of three weak states in the continent's southeastern periphery, the stormy political agitation in Romania was far from finished. Even before the conclusion of the treaty, motions were filed in the Parliament, and young students protested in Bucharest in defence of the national cause. An open letter was sent to Georges Clemenceau, the leader of the French radicals, by the Romanian students in Paris. France was denounced as 'the accomplice of Austria', who wanted to instil its economic hegemony over Romania. ${ }^{85}$

By March 1883, the political elite and public opinion in Bucharest were unanimous in condemning the unjust decisions of the Great Powers. The official position of the government on the London Treaty was made public in May 1883. After a presentation about Romania's efforts to safeguard free navigation on the Lower Danube and the country's right to take part in the London conference, Foreign Minister Sturdza announced that Romania considered the treaty as not binding, and it refused to accept six of its nine articles. ${ }^{86}$

But during the following months, a gradual shift in Romania's foreign policy started to become visible, and its diplomats were instructed not to take further steps in the Danube Question. Romania was to seek a direct agreement with Austria-Hungary and escape the isolation in which the country found itself. Germany encouraged such a rapprochement, beneficial for the consolidation of peace in Europe with 'happy results in the Danube Question'. Brătianu had talks with Bismarck and the Viennese Foreign Minister, Count Gustav Kálnoky, and by mid-September the Austrian-Hungarian cabinet decided to waive the application of the London Treaty, judging that Romania's pledges provided sufficient guarantees to preserve the empire's interests at the Lower Danube. ${ }^{87}$ A secret defensive treaty was signed by Romania and Austria-Hungary on

\footnotetext{
$84 \quad$ Navigation du Danube, 65-68; Sturdza, Recueil de documents, 472-474.

85 'Adresa studenților români din Paris către deputatul Clemenceau,' Resboiul, no. 2010, 14 February 1883: 2.

86 Cestiunea Dunării. Acte și documente, 905-912; Sturdza, Recueil de documents, 416a-416m (Sturdza to Ion Ghica, 24 May 1883).

87 Gheorghe Nicolae Căzan, 'La question du Danube et les relations roumano-austrohongroises dans les années 1878-1883,' Revue Roumaine d'Histoire 18.1 (1979): 43-61; Căzan and Rădulescu-Zoner, România și Tripla Alianță. 1878-1914 (Bucharest 1979), 93; Documente Diplomatice Române, series I, vol. 11, 1883, edited by Alin Ciupală, Rudolf Dinu and Antal Lukács (Bucharest 2006), 398-399 (No. 388, Ion C. Brătianu to Sturdza, Gastein, 7 September 1883).
} 
30 October 1883 , to which Germany adhered the same day. ${ }^{88}$ Russia was the unnamed enemy in a treaty which was prolonged several times during the next three decades, marking Romania's de facto adherence to the Triple Alliance. It can be stated that Romania's foreign policy was directed, to a large extent, by the government's decision to reach a satisfactory agreement in the complicated Danube Question. The alliance remained the secret of a handful of statesmen, never discussed or approved in the country's Parliament. It did not prevent, however, further disputes between Romania and Austria-Hungary, and by the mid-188os the two states started a long customs war that marked a new stage in the construction of Romania's national economy. Throughout the following decades, relations with Vienna and Budapest further deteriorated, but Germany was the partner Romania really wanted. The 1883 deal was a functional solution to the Danube Question, as the MCLD was never created. Romania's sovereignty was respected, but many in the country, noticing the rapprochement between Bucharest and Vienna, felt that the cause of the Transylvanian brethren had been betrayed.

Romania's resistance to the Great Powers' will in $1878-1883$ was motivated by the belief that its cause was not only morally, but also juridically right. The case was followed with great interest and discussed by experts in international law and international relations, who considered it illustrative of the structure and workings of the international system.

Several legal opinions were formulated by some of Europe's leading experts. One of them was Édouard-Philippe Engelhardt, the former French delegate to the Commission. In several pieces, he insisted on the justice of Vienna's position, given its vital economic interests at the Iron Gates and along the Fluvial Danube. It was true that Austria-Hungary was not a riparian state on that river section, but given that Europe had charged the Double Monarchy with the task of improving that difficult passage, 'could we consider as normal, I would even say as equitable, an exclusion which would place the immense Austrian-Hungarian traffic under the control of three new states, one of which is not even sovereign, and which, with their commercial fleet, play an insignificant part in Danube's navigation?' Not only economic reasons, but juridical

88 Documente Diplomatice Române, 476-478 (No. 444); the context in Căzan and RădulescuZoner, 'Tratatul secret de alianță între România și Austro-Ungaria (1883),' Revista română de studii internaționale 7.1 (1973): 175-194. 
ones supported Vienna's claims. IOs such as the Central Commission for the Navigation of the Rhine, the Commission and the MCLD existed through a delegation of sovereignty to a collective authority, which was exactly what Austria-Hungary was requesting at the time. ${ }^{89}$

To Georg Jellinek, an eminent professor of public law at Vienna University, the international system was about power relations and the pursuit of purpose. Interdependence pushed rational state actors into cooperation, which sometimes resulted in the delegation of sovereignty and creation of international institutions. ${ }^{90}$ There was nothing wrong about Vienna looking to exercise a legitimate influence and reasonable preponderance, and it was completely imprudent for Romanian statesmen to isolate the country, instead of seeking cooperation with its more powerful neighbour. As long as the imperial hegemony was kept within proper limits, it could be regarded as a means of supporting the existence of weak riparian states rather than as an instrument to absorb them. Jellinek regarded Vienna's influence as positive for developing commerce and increasing the prosperity and security of small states. The future would belong to international organs, and general interests had to prevail over private ones through cooperation, as envisaged by the 1815 principles. ${ }^{91}$ Another Viennese legal expert, Leo Strisower, had placed the dispute in a similar framework: the selfish tendencies of backward states fighting against the influence of larger nations that struggled for free and unobstructed trade had to be combatted. ${ }^{92}$

But such opinions were rejected not only by Romanian legal experts, ${ }^{93}$ but also by many members of the Institute of International Law. One of them was German Baron Franz von Holtzendorff, elected president of the IIL at the organisation's Munich 1883 session. Holtzendorff was invited to provide juridical advice to the Romanian government and he was not short of criticism for the Great Powers. The international system was based on the idea of free consented agreements by states, and in international river commissions the recognition of their absolute rights as executive powers was vital. Romania's rights had been recognised by its acceptance into the Commission on an equal

89 Éd. Engelhardt, 'La Question du Danube. Étude critique,' RDILC 15 (1883): 5-16; idem, 'La question du Danube, après la Conférence de Londres,' ibid.: 340-347; idem, 'Le droit fluvial conventionnel et le Traité de Londres de 1883,' ibid., 16 (1884): 360-373.

90 On his juridical views, see Koskenniemi, The Gentle Civilizer, 198-206.

91 Georg Jellinek, Oesterreich-Ungarn und Rumänien in der Donaufrage: eine völkerrechtliche Untersuchung (Vienna 1884).

92 Leo Strisower, 'Die Donaufrage,' Zeitschrift für das Privat- und öffentliche Recht der Gegenwart 11 (1884): 680-727.

93 Such as Valerian Ursiano, L'Autriche-Hongrie et la Roumanie dans la question du Danube (Iași 1882). 
footing with Europe's Great Powers. Austria-Hungary had many legitimate rights but imposing them did not mean that other weak states had to sacrifice their own interests. After giving an historical account of the Danube Question, the German scholar discussed the main juridical implications of the case in the form of nine questions that focussed on the exceptional legal situation of the Lower Danube. These included complicated points such as the fact that recognition of a state's sovereignty could not be wholly or partly revoked and that a non-riparian state's rights could not be extended to the detriment of a riparian country. ${ }^{94}$

For Theodor von Bunsen, a German diplomat, jurist and liberal politician, the conflict had a much larger international relevance than the usual strife between a small state and a Great Power, as it touched upon the very founding principles and functioning of Europe's Concert. The diplomatic meeting in London questioned the importance of international conferences, the decisions of the Great Powers, and the position of a state which opposed their general will: 'The supreme control of Europe's affairs by the Great Powers is the capital fact of nineteenth century politics', and the first step towards a closer organisation of European nations into a 'great family'. But the London Conference also proved that Europe's leading states used such meetings not for a greater general good, but mainly to advance their own political agenda to the detriment of smaller states. To Bunsen, who reviewed several volumes published on the topic by international scholars, ${ }^{95}$ it was no bad sign that most of them, writing independently of the others, had arrived at the same opinion: in opposing the decisions of the 1883 Conference, Romania 'only maintains its right' and 'defends the principle of the freedom of navigation', threatened by the diverging interests of Europe's leading powers. ${ }^{96}$

The interest in the Danube Question and the Commission was manifest at the time in the discussions at the Berlin Conference, convened to transpose Europe's models of cooperation to the African colonies. Fourteen states attended the conference between November 1884 and February 1885, and legal experts from the IIL were among them. The conference aimed to solve several important topics, including the establishment of freedom of commerce on the Congo River and freedom of navigation on the Congo and Niger Rivers. In their discussions, the Danube and its commissions were mentioned as models of

\footnotetext{
94 Holtzendorff, Les droits riverains cit.

95 Among them F.H. Geffcken, La question du Danube (Berlin 1883); F. Dahn, Eine Lanze fur Rumänien (Leipzig 1883); E.-L. Cattelani, La Navigazione fluviale e la questione del Danubio (Turin 1883).

96 Theodor Bunsen, 'La Question du Danube,' RDILC 16 (1884): 551-567.
} 
international cooperation, able to bring commercial rationality and civilisation to that area. In his opening remarks, Bismarck linked European exploration and commercial movements along the river to the service of peace and humanity. But the conference remained divided on how the Congo Commission would execute its vast attributions, in many ways similar to those of the Danube Commission, and the colonial organisation was never summoned. ${ }^{97}$

This encouraged the IIL to continue its transnational epistemic work of discussing and codifying the rules for the management of international rivers. A proposal was made by Martens in 1885 , concerning which riparian states were to carry out administrative tasks through river commissions. ${ }^{98}$ Engelhardt had his own version, somewhat more exclusivist, as it reserved internal cabotage to riparian states, which could grant this right to the commercial fleets of other nations. ${ }^{99}$ Discussions followed in 1887 , at the institution's annual conference, when other jurists contributed their own comments and adjustments. Eventually, on 9 September 1887 , the IIL voted on a regulation that followed Martens' view. The project defended the rights of riparian countries, with full observance of their national sovereignty. River management was to be entrusted to river commissions, whose attributions resembled the institutions active on the Rhine and Danube. ${ }^{100}$ But the jurists' normative work was to have little practical influence, and it serves here to illustrate the making of professional networks of scholars, and their interest for encouraging cooperation between states and the peaceful resolution of international disputes.

Romania's political decision in 1883 was to move away from the tyranny of public opinion towards concessions made through secret diplomacy, conducted by an enlightened elite. As Carp, one of the artisans of the 1883 Treaty in his capacity as Romania's ambassador to Vienna, had noticed, popular sentiments were not necessarily oriented towards peace, and it took wise statesmen to steer the ship out of dangerous waters. The episode marks a more realist turn

97 Yuan (Joanne) Yao, Constructing the Ideal River: the 19th Century Origins of the First International Organizations, PhD dissertation, London School of Economics and Political Science (London 2016), 168-188.

98 'Projet de règlement international de navigation fluviale présenté à l'Institut de Droit International dans la session de 1885, par M. de Martens,' RDILC 19 (1887): 171-174.

99 'Projet de convention sur la navigation des fleuves internationaux présenté par M. Éd. Engelhardt et extrait de la seconde édition (non encore publiée) de son livre: "Du régime conventionnel des fleuves internationaux,"' ibid.: 253-257.

100 'Règlement international de navigation fluviale, adopté par l'Institut de Droit International,' ibid., 355-36o; see also Resolutions of the Institute of International Law Dealing with the Law of Nations, with an Historical Introduction and Explanatory Notes, collected and translated under the supervision of and edited by James Brown Scott (New York 1916), 63-64. 
in Romanian politics, and an orientation towards stability that came with understanding that the country had a regional and European responsibility after gaining state independence.

Romanian statesmen agreed, beyond partisan politics, that the country belonged to the large family of European states. As many of them were educated in the juridical schools of Western Europe, they envisaged 'Europe' as an association of independent states, but also as a community based on common historical values and juridical principles. Europe's Concert was a legitimate institutional framework for mediating the balance of the international system, where decisions were taken during conferences, and through treaties and clear dispute-settlement procedures. It was in Romania's best interests to accept this mechanism which had guaranteed its political existence. Independence meant inclusion in this family of nations, ruled by asymmetric and sometimes unjust (as was the case with the 1883 London Treaty), but functional laws.

The Commission was an embodiment of Europe's Concert, and the Romanian decision-makers accepted its positive role in advancing the country's national interests not only through its hydraulic programme, but also by impeding an exclusive hydro-imperial domination in the area. The Commission had contributed tremendously to the economic development of Danubian port-cities, but from the 1870 s onwards it also assumed a significant political role at the Maritime Danube. The 1878 Berlin Treaty reconfirmed this status and increased the Commission's role, to the detriment of Romania's sovereignty. But equally it made Romania a member of this IO and consecrated its new status in the family of independent states.

After the 1883 London Conference, the Commission became a de facto permanent organisation. No member state required its dissolution until the First World War, and in the early twentieth century several requests came from Bulgaria, Serbia and Greece to join in the institution. The eight commissioners continued to meet twice a year at Galați to decide on the daily business of the institution, whose budget continued to grow. One of its increasingly serious problems was, however, growing nationalism from some Romanian statesmen, who started to question the Commission's large attributions and its violations of Romania's sovereign rights. ${ }^{101}$ Such contestations from riparian states, as

101 Iorga, A cui e Dunărea? (Conferință ținută la Giurgiu în ziua de g noiembrie 19o8) (Vălenii de Munte 1908). 
Chapter 10 will show, continued into the interwar period and eventually transformed the Commission into an organisation that more closely resembled the Central Commission for the Navigation of the Rhine.

Sovereignty has been an important component of this story. In the long nineteenth century, sovereignty came with a rhetoric of honour and virtue, both imbued with the idea of 'manliness'. Honour, virtue and prestige had been significant markers that shaped the attitude of both imperial powers and young nation-states in relation to their sovereignty. Russian statesmen reclaimed Bessarabia to heal their Tsar's wounded honour, and they could not accept a foreign presence on the Chilia branch, while Romania's honour was violated by the hydro-hegemonic claims of its imperial neighbours. But as the same Carp put it, 'by stripping off part of our sovereignty' and by accepting a multilateral protectorate over Danube's navigation, Romania could be 'stronger than by keeping a harmful pride'. 